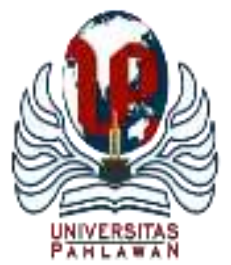

Edukatif : Jurnal Ilmu Pendidikan Volume 3 Nomor 6 Tahun 2021 Halm 4234 - 4244

EDUKATIF: JURNAL ILMU PENDIDIKAN

Research \& Learning in Education

https://edukatif.org/index.php/edukatif/index

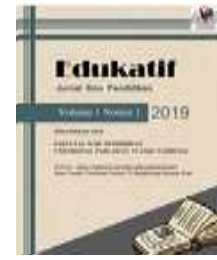

\title{
Anti-Corruption Values Potrayal in English Textbooks for Senior High School Grade XII: Critical Discourse Analysis Perspective
}

\author{
Prayogo Hadi Sulistio $^{1 凶}$, Erna Wardani $^{2}$ \\ Universitas Jenderal Soedirman, Indonesia ${ }^{1,2}$ \\ E-mail : sulistio.prayogohadi@unsoed.ac.id ${ }^{1}$, erna.wardani@ unsoed.ac.id ${ }^{2}$
}

\begin{abstract}
Abstrak
Penelitian ini bertujuan untuk mengetahui penggambaran nilai antikorupsi pada buku pelajaran bahasa Inggris kelas XII sekolah menengah atas. Penelitian ini menggunakan analisis isi. Pengumpulan data dilakukan dengan menentukan nilai antikorupsi yang terbagi menjadi tiga yaitu: nilai inti, nilai sikap dan nilai etos kerja kemudian mengelompokkan teks bacaan, dialog dan ilustrasi yang mewakili ketiga nilai antikorupsi tersebut dan menginterpretasikan penggambaran nilai antikorupsi. menurut data yang ditemukan. Hasil penelitian ini menunjukkan bahwa ketercakupan nilai antikorupsi dalam buku teks secara dominan menggambarkan nilai kejujuran, kepedulian dan kerja keras dalam dialog, teks bacaan dan ilustrasi. Lebih jauh lagi, nilai antikorupsi direpresentasikan dengan berbagai macam ekspresi seperti peduli, empati, tanggung jawab dengan berbagai konteks selain untuk meningkatkan kemampuan interpersonal siswa namun juga membiasakan siswa untuk mengaplikasikan nilai yang mereka temui di dialog, teks bacaan, dan ilustrasi dalam kehidupan sehari-hari. Hal ini menunjukkan bahwa penulis buku ajar telah mengupayakan untuk memasukkan nilai antikorupsi sebagai bagian dari pendidikan antikorupsi yang diinisiasi oleh Komisi Pemberantasan Korupsi bekerja sama dengan pemerintah.
\end{abstract}

Kata kunci: Nilai Antikorupsi, Buku Pelajaran Bahasa Inggris, Analisis Wacana Kritis

\begin{abstract}
This study is aimed to investigate anti-corruption values portrayal in English textbooks for senior high school grade XII. This research used content analysis. Data collection was carried out by determining anticorruption values which were divided into three, namely: core values, attitude values, and work ethic values then grouping reading texts, dialogues, and illustrations representing the three anti-corruption values and interpreting the implementation of anti-corruption education according to the data found. The results of this study indicate that the coverage of anti-corruption values in textbooks dominantly presents honesty, care, and hardworking values in dialogues, reading texts, and illustrations. Furthermore, anti-corruption values are represented by various expressions such as caring, empathy, responsibility in various contexts not only to increase students' interpersonal skills, but also to apply anti-corruption values that the students find in dialogues, reading texts, and illustrations in daily life. It shows that the authors of the textbooks have tried to insert anti-corruption values as part of anti-corruption education initiated by the Corruption Eradication Commission in collaboration with the government.
\end{abstract}

Keywords: Anti-Corruption Values, English Textbooks, Critical Discourse Analysis

Copyright (c) 2021 Prayogo Hadi Sulistio, Erna Wardani

$\triangle$ Corresponding author:

Email : sulistio.prayogohadi@unsoed.ac.id

DOI : https://doi.org/10.31004/edukatif.v3i6.1420

ISSN 2656-8063 (Media Cetak)

ISSN 2656-8071 (Media Online)

Edukatif : Jurnal Ilmu Pendidikan Vol 3 No 6 Tahun 2021 p-ISSN 2656-8063 e-ISSN 2656-8071 
4235 Anti-Corruption Values Potrayal in English Textbooks for Senior High School Grade XII: Critical Discourse Analysis Perspective - Prayogo Hadi Sulistio, Erna Wardani

DOI: https://doi.org/10.31004/edukatif.v3i6.1420

\section{INTRODUCTION}

Currently, many government officials and businessmen have been caught in the Sting Operation organized by the Corruption Eradication Commission (KPK). This is in contrast to the spirit of nationality where all parties should work hand in hand to build this country. The latest data released by Transparency International shows that Indonesia's position in the corruption perception index is at number 89 (Tendi, 2019). Indonesia is still under Brunei, Malaysia, and Singapore. Furthermore, corruption is seen as an extraordinary crime whose resolution takes precedence (Ifrani, 2017). As an extraordinary crime, corruption causes a lot of miseries, especially for the people. So it takes an active role from all parties, starting from the Attorney General's Office, the Police, the Corruption Eradication Commission (KPK), and related institutions to break the cycle of corruption in Indonesia.

The Corruption Eradication Commission (KPK) as an official institution under the President has special authority to eradicate corruption in Indonesia. One of the ways to eradicate corruption is anti-corruption education which is intended for all levels of formal education from elementary, junior high, high school, and tertiary education. The Ministry of Education and Culture (2018) explains that the anti-corruption education policy initiated by the KPK is to strengthen character education which does not mean the addition of subjects in the curriculum but an innovative and creative learning process in implementing anti-corruption education. Thus, the cooperation that exists between the KPK and the Ministry of Education and Culture through anticorruption education is capable to eradicate existing corruption.

As a major problem in many countries especially in Indonesia, corruption becomes a common enemy for all people in the world and also in Indonesia. The massive practice of corruption that occurs can create a systemic effect to make a country bankrupt and unable to provide adequate public services (Zuber, 2018). To curb corruption, the government needs to have careful planning and an effective strategy. Simbolon (2016) describes a strategy to eradicate corruption in the form of a pyramid which at its peak is enlightenment and the two sides of the pyramid are public education and punishment. Therefore, two fundamental things needed to eradicate corruption are strong commitment and cooperation from all parties from the public and private sectors.

Seeing the importance of public education as a means of eradicating corruption, the Corruption Eradication Commission has developed anti-corruption education that can be implemented at every level of formal education. Furthermore, the KPK (2017) explains the values forming anti-corruption behavior are divided into three parts. The first is the core values which include honesty, discipline, and responsibility. The second is the attitude values which include fairness, bravery, and care. The third is the work ethic values that include hard-working, modesty, and independence. It is hoped that the values forming anti-corruption behavior can be integrated into the learning process. In addition, anti-corruption education has the main objective of cultivating anti-corruption behavior from an early age. In line with this, Sjahrudin (in Kristiono, 2018) explains that anti-corruption education has four main objectives, are: 1) students have sufficient provisions to understand ethics at each level of 'social leaders' they live in society; 2) students have a good understanding of ethics in the public and private sectors; 3) students are able to understand and recognize the impact caused by corruption, especially on public trust and global competition; 4) students have the courage and wisdom to eradicate corruption.

As a supporter of the learning process, textbooks play an important role not only to provide exercises that are intended to improve students' cognitive abilities but also to strengthen character education such as anti-corruption education. In line with this, Dharma \& Aristo (2018) elaborate that textbook has two main pedagogic functions in terms of curricular aspect to improve progress in the subject being taught and conceptual aspect to develop cognitive structures for the students. Knight (2015) elaborates that textbook becomes so critical to facilitate the learning process. It covers various learning materials, learning sources, and 
even background reading so that it may help teachers in delivering materials for the subjects being taught. Rohmatillah \& Pratama (2017) explains that textbooks become a major source of learning activities, a source of teaching material, a source of vocabulary, sentence structure, intonation which is very useful for students and teachers. Furthermore, Herlinda (2014) explains that textbooks provide written and oral learning materials which include learning activities related to language learning such as grammatical learning, vocabulary, narrative and providing ideas in the preparation of learning designs, providing guidelines in giving assignments to students and helping teachers to standardize instruction in learning. Textbook becomes influential media in teaching English and it also contains various resources that can be used by teachers in teaching English in the classroom (Sholikha \& Fitrayati, 2021). So seeing this fact, textbooks play a crucial role in the learning process in the classroom so that textbooks can be a tool to socialize anti-corruption education in formal education.

Previous studies examine about moral values presented textbooks have been conducted by seeing moral values in the narrative text of the EFL textbook (Setiawan \& Fahriany, 2017). They found that kindness is the most frequent value being portrayed while fairness becomes the least frequent value being portrayed in the narrative text in English textbooks for senior high school level. Furthermore, Nadhif (2017) found that there are several dominating ideologies and moral values being inserted in the textbook. They are western style of greeting people, luxury furniture in the house of rich people, and the notion of being pretty in certain ways with white skin and straight hair. Students at the end may internalize moral values that they are being exposed to daily life activities. Furthermore, Sulistio and Wardani (2020) found that anti-corruption values are being portrayed in the English book entitled Buku Siswa Pelajaran Bahasa Inggris Sekolah Menengah Atas kelas XII published by the Ministry of Education and Culture. The anti-corruption values are frequently portrayed as work ethic values 54 times, core values are represented 47 times and attitude values are represented 44 times. The topics which insert anti-corruption values are so various like group discussion conversation, news articles about the assertiveness of police officers, reading text with the main topic like recycling garbage to encourage students to become more aware of their environment. Thus, it can be seen that government already implements anti-corruption education in the English Textbook being published by the Ministry of Education and Culture. However, there is little known about anti-corruption values portrayal in EFL textbooks especially published by private companies. Most researchers in Indonesia focused mostly on moral values infused in EFL textbooks. So that, this paper analyzes anti-corruption values in EFL textbooks published by private companies from a critical discourse perspective in the level of senior high school grade XII. Students at the high school level are selected because at this level, students are good enough and mature enough to respond to corruption problems around them. So that they are able to adapt anti-corruption values into their daily lives and prepare for higher levels, higher education.

\section{RESEARCH METHODOLOGY}

This study used critical discourse analysis. It is because textbooks as educational texts contain various meanings through verbal and non-verbal languages (Widodo, 2018). Furthermore, Sulistiyo et al. (2020) explain that textbooks can be examined by textual analysis because the textbook itself is an educational discourse. Textbook as learning sources contains various materials to improve students' language skills (Wulandari et al., 2018). Thus, a textbook can be analyzed in various ways and one of the typical analyses usually being used is critical discourse analysis. Mandarani et al. (2021) explain that critical discourse analysis may help to connect the text and discourse in the cultural and social context in the community where the textbooks are being used. Looking at the previous explanation, Critical discourse analysis is an appropriate research method for analyzing textbooks looking at anti-corruption values being represented in English textbooks for high school grade XII. 
The data being used in this study were from two English textbooks for grade XII. The first book is Buku Teks Pendamping: Bahasa Inggris which is published by Yrama Widya. The second book is Pathway to English which is published by Erlangga. Both of the textbooks are written by EFL practitioners and English teachers in Indonesia. Both of the books are widely used in Indonesia.

To collect data from the analyzed high school English textbooks, the researcher took two main steps, namely: 1) To categorize anti-corruption values into three main parts (core values, attitude values, and work ethic values); 2) Determine dialogues, reading texts, and illustrations that represent anti-corruption values in English textbooks.

To analyze the collected data, the researcher took several steps, namely: 1) Collecting dialogues, reading texts, and illustrations that represent anti-corruption values in English textbooks; 2) Classifying dialogues, reading texts, and illustrations according to the core values, attitude values, and work ethic values of anti-corruption values; 3 ) Determine the frequency of appearance of core values, attitude values and work ethic values seen from dialogues, reading texts and illustrations; 4) Discuss findings regarding the implementation of anti-corruption values in English textbooks; 5) Draw conclusions from the data found.

\section{FINDINGS AND DISCUSSION}

This section shows frequency analysis of anti-corruption values in both textbooks from dialogues, illustrations, and reading text. Researchers found that the representation of anti-corruption values in the first textbook is quite impressive with core values becomes the most frequent being represented.

Table 1

Anti-corruption Values in English Student Textbook for Senior High School Grade XII Published by Yrama Widya

\begin{tabular}{|c|c|c|c|c|c|c|c|c|c|}
\hline \multirow[t]{2}{*}{ Chapter 1 -7 } & \multicolumn{3}{|c|}{ Core Values } & \multicolumn{3}{|c|}{ Attitude Values } & \multicolumn{3}{|c|}{ Work Ethic Values } \\
\hline & Honesty & Discipline & Responsibility & Fairness & Bravery & Care & $\begin{array}{l}\text { Hard } \\
\text { working }\end{array}$ & Modesty & Independence \\
\hline Dialogue & 4 & & 6 & & & 17 & 2 & 2 & 1 \\
\hline $\begin{array}{l}\text { Reading } \\
\text { Text }\end{array}$ & 51 & 2 & 36 & 26 & 1 & 3 & 28 & & 6 \\
\hline Illustration & 4 & 7 & 26 & 1 & 1 & 13 & 31 & 1 & 11 \\
\hline Total & 59 & 9 & 68 & 27 & 2 & 33 & 61 & 3 & 18 \\
\hline & 136 & & & 62 & & & 82 & & \\
\hline
\end{tabular}

Based on the table above, researchers found that Core values have the highest distributions which are 136 times being represented. Responsibility is the highest in this part with 68 times presentation. Honesty is the second highest representation with 59 times portrayal. The lowest representation is a discipline with only 2 times in this textbook. Work Ethic values become the second highest representation in this book with 82 times. Hard-working is the highest representation in this part with 61 times. Independence has been presented 18 times. The lowest representation in this part is modesty with only 3 times in this textbook. Attitude values are the least values being presented in this textbook with 44 times representation. Care has the highest representation with 33 times. Fairness is being presented 27 times. Bravery becomes the least being presented with only 2 times.

Researchers found that in the second textbook core values become the most frequent being portrayed, followed by work ethic values and the last is attitude values. 
4238 Anti-Corruption Values Potrayal in English Textbooks for Senior High School Grade XII: Critical Discourse Analysis Perspective - Prayogo Hadi Sulistio, Erna Wardani

DOI: https://doi.org/10.31004/edukatif.v3i6.1420

Table 2

Anti-corruption Values in English Student Textbook for Senior High School Grade XII Published by Erlangga

\begin{tabular}{|c|c|c|c|c|c|c|c|c|c|}
\hline \multirow{2}{*}{$\begin{array}{l}\text { Chapter } 1 \\
10\end{array}$} & \multicolumn{2}{|c|}{ - Core Values } & \multicolumn{4}{|c|}{ Attitude Values } & \multicolumn{2}{|c|}{ Work Ethic Values } & \multirow[b]{2}{*}{ Independence } \\
\hline & Honesty & Discipline & Responsibility I & Fairness & Bravery & Care & $\begin{array}{l}\text { Hard } \\
\text { Working }\end{array}$ & Modesty & \\
\hline Dialogue & 16 & 6 & 14 & 1 & 10 & 8 & 9 & & 8 \\
\hline $\begin{array}{l}\text { Reading } \\
\text { Text }\end{array}$ & 38 & 13 & 23 & 8 & 8 & 15 & 19 & 3 & 8 \\
\hline Illustration & 3 & 20 & 11 & 2 & 2 & 5 & 27 & 5 & 17 \\
\hline \multirow[t]{2}{*}{ Total } & 57 & 39 & 48 & 11 & 18 & 28 & 55 & 8 & 33 \\
\hline & 144 & & & 57 & & & 96 & & \\
\hline
\end{tabular}

The most reflected anti-corruption values are the core values with 144 times representation. Honesty is the highest represented value with 57 times. Furthermore, the value of responsibility is represented 48 times. The value of discipline is the lowest represented by 39 times. Furthermore, the values of work ethic are represented 96 times. Hardworking values are the most represented value with 55 times portrayal. Independence is represented 33 times. The lowest is a modesty value of 8 times representation. Attitude values are the least represented value with only 57 times. Care becomes the most represented value with 28 times. Bravery was represented by 18 times. Fairness is the lowest represented by 11 times.

\section{Narrative analysis results}

In addition to frequency analysis of anti-corruption values representation, this study analyzes the samples from dialogue given in the textbook related to anti-corruption values. Care becomes the most frequent anti-corruption value in Buku Teks Pendamping: Bahasa Inggris and honesty becomes the most frequent anticorruption value in Pathway to English.

Text 1:

Ratu : I read the instructions more than twice, but I am still not sure how to operate my mobile phone

Dewa : Actually, it is so simple. First of all, do not forget to turn it on.

Ratu : I see

Dewa : Then dial the number. After that, remember to press the "send" button.

Ratu : Got it. Is that all?

Dewa : Yes, just make sure to recharge the batteries every few days and try not to drop it. It is fragile.

Ratu : I will remember that. Thanks for your help.

Dewa : And one more thing, be sure to buy the minutes before the active period is over.

(Buku Teks Pendamping: Bahasa Inggris, p.109)

The dialogue itself takes place between two friends who discuss how to operate a mobile phone. it shows that Ratu does not know how to operate her mobile phone. Then, Dewa tries to help. It is implicitly, he cares about Ratu's condition so that he helps her. Dewa explains the instruction honestly so that the mobile phone can operate well. It also represents that these two persons are independent. The textbook writes use statement like Got it. Is that all? It shows that these two persons are in an informal situation. They are seemed to be close enough like they are not far different in terms of age. In line with this fact, Schat (2018) explains that students who have difficulties especially related to their daily activities will attract empathy from other students. So that they can communicate with each other to seek a better solution for the burdens being faced by other students who struggle. The caring relationship is unique and the uniqueness will become the foundation of honor for this kind of relationship.

Text 2:

Pharmacist : Hello, may I help you? 
4239 Anti-Corruption Values Potrayal in English Textbooks for Senior High School Grade XII: Critical Discourse Analysis Perspective - Prayogo Hadi Sulistio, Erna Wardani

DOI: https://doi.org/10.31004/edukatif.v3i6.1420

Mahadewi : Yes, please. Could I have something for my cough?

Pharmacist : Well, it depends on what kind of cough you are suffering. If you have whooping cough, you should take these pills. If you are suffering from cough with phlegm, you have better take these tablets. And if you have hacking cough, why don't you take this cough syrup? But if your cough is spitting up of blood, see a doctor promptly.

Mahadewi : Cough syrup, please. And what do you suggest for dry skin?

Pharmacist : If you have dry skin, try this new lotion. It is very good.

Mahadewi : Okay, and one more thing. I feel languid these days. Can you suggest anything?

Pharmacist : If your body is weak, try these multivitamins. And if you feel lethargic, why don't you take this booster energy drink?

Mahadewi : Great! Give me five large bottles, please.

Pharmacist : Sure, anything else?

(Buku Teks Pendamping: Bahasa Inggris, p.93)

The dialogue is initiated by the pharmacist. It can be seen that the pharmacist care for the customer by asking the customer about the help he or she might need. The greeting from the pharmacist is replied to politely by the customer using yes, please and the dialogue is followed by the polite request by the customer using the statement could I have something for my cough? The pharmacist in giving the suggestion for the medicine using should which is the polite utterance in this dialogue. The writers of the textbook trying to emphasize that the feeling of care is based on the responsibility that the pharmacist has in doing his or her job. Even in this case, the pharmacist's intention is mostly seeking financial advantage but the pharmacist still expresses the feeling of care to the customer to cure the disease that the customer is suffering. Purwanto \& Soepriatmadji (2013) explain that the conversations which involve requests and offer expressions encourage persons in the dialogue to improve interpersonal skills.

Text 3:

Sandra : What do you think we should do about video games?

Leslie : In my opinion, video games offer a lot of benefits. They can relax a child's mind after a tiring day at school.

Sandra : Actually, I am not sure about that. According to the article I read, video games make children lazy. Playing video games is addictive. Therefore, many children prefer playing video games to studying.

Leslie : I don't think that's very good argument because video games can trigger children to be more creative. The games provide a challenge that can sharpen their brains.

Sandra : Sorry, I don't see it that way. There is no easy solution to this dilemma.

(Pathway to English, p.108)

The dialogue takes place between two students who discuss the pros and cons of playing video games for students. It can be seen that they have a different source of argumentation point. Leslie argues based on her opinion regarding the good sides of playing video games related to her statement, in my opinion, video games offer a lot of benefits. However, Sandra's argumentation is based on the article she reads and it can be seen from her statement according to the article I read. Both of them speak honestly based on the source they refer to. In the end, they agree to disagree with this regard. The expression of argumentation being used is always contrary one to another by having a statement like I don't think that's a very good argument and Sorry, I don't see it that way. The writers of the textbook try to emphasize the encouragement of speaking honesty based on the opinion and data. Furthermore, Rapanta \& Christodoulou (2019) explain that students develop in constructing valid arguments based on the evidence they have while involving in argumentative dialogue so the students may learn how to exploit the evidence based on their purposes. 
4240 Anti-Corruption Values Potrayal in English Textbooks for Senior High School Grade XII: Critical Discourse Analysis Perspective - Prayogo Hadi Sulistio, Erna Wardani

DOI: https://doi.org/10.31004/edukatif.v3i6.1420

Text 4:

Student 1 : Well, what does the Corruption Eradication Commission handle?

Student 2 : KPK investigates and prosecutes cases of graft.

Student 1 : Graft? What is that?

Student 2 : Okay, let's look up the meaning at the dictionary. Here it is. Graft is bribery. Such dishonest activities can be achieved, for example, by taking advantage of political power.

Student 1 : Let's see the report. KPK only convicted two anti-graft judges.

Student 2 : You are right. The number of people prosecuted by Indonesia's Corruption Eradication Commission was recorded 19 in 2007, but it increased to 35 in 2008.

(Pathway to English, p.32)

This dialogue shows a discussion between two students who talk about corruption and the function of KPK in general. There is an effort to educate the students by increasing awareness about one type of corruption in this case graft. They talk honestly based on the data and are brave enough to discuss this even sometimes discussing crime like corruption seems taboo. Both of the students have a great curiosity in seeking the meaning of graft and appreciate the data they get from the report. The textbook writers make a conversation about corruption can be done in the class so that the awareness of the students of this matter is increasing.

\section{Illustration Analysis Result}

The textbook writers also try to integrate anti-corruption values by many means in the textbook. This study also analyzes how illustration as a part of the textbook also becomes a tool for the writers to implicitly insert anti-corruption values.

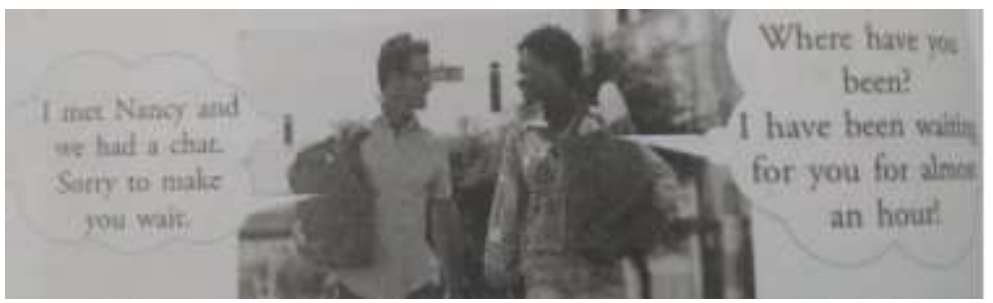

Picture 1. Pathway to English, p.74

In this dialogue using illustration, the writers of the textbook intend to emphasize the importance of being punctual and disciplined. When two persons already make a schedule to meet in a certain place and certain time, they are obliged to obey the schedule. In this matter, a man tries to explain why he comes late. Even, he speaks the truth, he already disappoints her. Even though these two persons seem close enough but still it does not make being late allowed. Furthermore, it is important to tell someone you have a schedule with if you are going to be late so that he or she knows where you are going if you are not able to come on time. Thus in any culture especially in Indonesia, being punctuate and discipline based on the schedule is important. It shows respect to the other person.

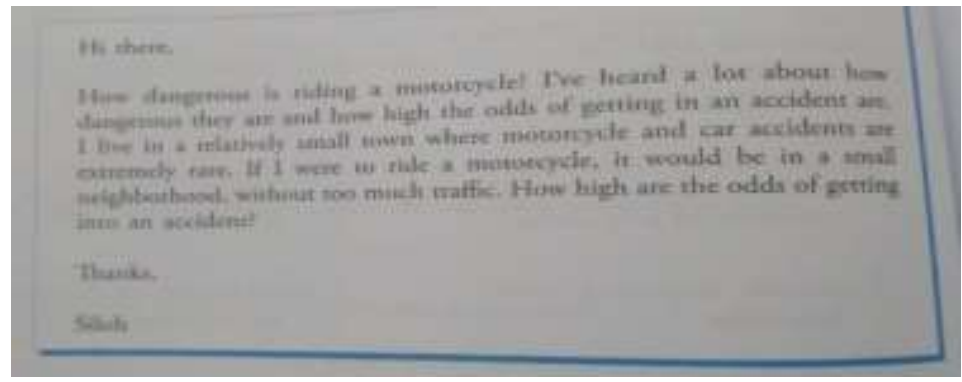

Picture 2. Pathway to English, p.120 
The letter itself is not quite familiar regarding the daily life context. The discussion about the odds of getting an accident is not a daily topic being discussed especially using a letter. In this matter, Silo expresses his curiosity regarding getting accidents while riding a motorcycle because he rarely sees accidents in his hometown as he explains that he lives in a small town. Furthermore, Siloh seems he does not have a close friend so that he writes this to ask a question to somebody out there. Siloh also in this letter expresses the attitude of people in his hometown that they are responsible and discipline in the street so that they can avoid an accident. He is also aware that a street is a dangerous place. The textbook writers try to emphasize the anticorruption values of responsibility and discipline in riding a motorcycle. Thus, he or she can avoid the accident by obeying the rules.

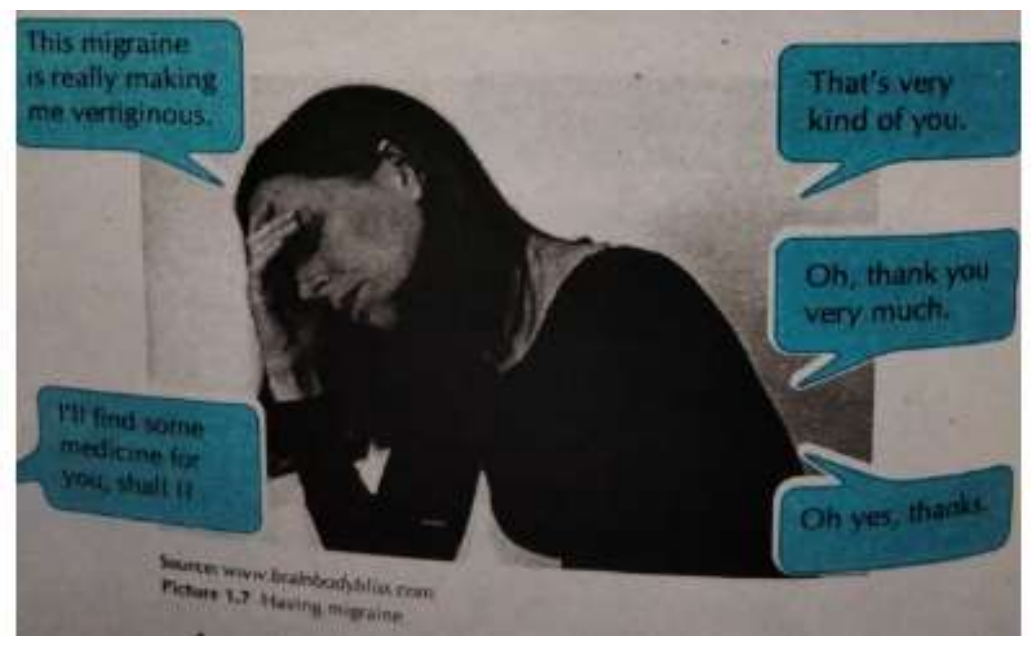

Picture 3. Buku Teks Pendamping: Bahasa Inggris, p.12

In this picture, a woman has a migraine and someone has empathy for her by giving her help to find medicine. The one who helps has great care for her. In reply, she answers thank you as an expression of gratitude for the help. Even, the picture is not quite clear that with whom the woman is having dialogue but it is clear there is a caring relationship and also the respect is can be captured by expression of gratitude. Dalilan (2012) explains that in Indonesian context the expression of gratitude is represented by simply saying thank you. This kind of simple thanking is viewed as a polite utterance for expressing gratitude for good deeds that somebody has done to us. From the illustrations being analyzed, there are some identified as fictional and nonfictional. It shows that the writers of the textbook have great intention to insert anti-corruption values in this part. The frequent representations found are related to discipline, care, and responsibility values. Wulandari \& Indihadi (2021) explains that illustrations being in the class as learning media may represent many meanings to even clarify something because the characteristics of illustrations themselves are concrete.

The findings show that the coverage of anti-corruption values that occurs in the two English textbooks for senior high school grade XII may vary, but the efforts being put to insert anti-corruption values becomes an inevitably important element. The findings show that honesty, care, and hardworking values are represented frequently in both textbooks through three elements of the textbook being analyzed which are dialogues, reading texts, and illustrations. Various contexts are being depicted in the textbook, such as school, pharmacy, scheduled meetings, and pen pal letters. The three major values being represented show that textbook writers intend to increase awareness of the anti-corruption of the students by applying these values in their daily life. Indonesia in this case is struggling in fighting corruption, in terms of materials and mindset. People of Indonesia should avoid any means of corruption in their life so that they can sharpen the intuition of fighting corruption by practicing honesty, care, and hardworking on daily basis. Furthermore, dialogues and illustrations analysis reflect efforts being put to insert anti-corruption values in so many ways. So that, teachers and students can apply those kinds of inputs regarding anti-corruption values in daily life. In line with 
4242 Anti-Corruption Values Potrayal in English Textbooks for Senior High School Grade XII: Critical Discourse Analysis Perspective - Prayogo Hadi Sulistio, Erna Wardani

DOI: https://doi.org/10.31004/edukatif.v3i6.1420

this, Sulistio \& Wardani (2020) explain that the textbook published by the government already covers anticorruption education. This research found that textbooks published by private companies also share the same commitment by inserting anti-corruption values in English textbooks. In contrast with previous research, this research applies narrative analysis that shows a wide range of social implications in familiarizing the anticorruption values for students.

The study being conducted regarding anti-corruption values portrayed in textbooks can be used as references about how to insert the various values in textbooks. This study also shows that the commitment to implementing anti-corruption education in every aspect of education especially in textbooks being used in the classroom. It is important that by using qualified textbooks which contains not only exercises of language skills also values that the students need to be exposed to.

\section{CONCLUSION}

Based on the findings of the study, the writers of the textbooks have the same commitment to inserting anti-corruption values in the textbooks being developed. The writers also have their own styles in inserting anti-corruption values by having many expressions which are intended not only to improve student's language skills and also familiarize anti-corruption values. Thus, English language learning also plays a significant role in this kind of corruption fighting that students not only study the language skills from the textbook but also they will learn anti-corruption values about the sample and how to apply anti-corruption values in an everyday situation. Also, the learning process is viewed as best practice to insert anti-corruption values. So that, from this kind of media, it will produce great students with a clear understanding about corruption and also the students may help to fight against the corruption as the agent of change. It is clear that anti-corruption-based education needs involvement by many parties so that it can be one solution to help against corruption these days.

\section{ACKNOWLEDGEMENTS}

We would like to express our gratitude to LPPM Universitas Jenderal Soedirman (Institution of Research and Community Service) for fully funded this research under the scheme Riset Dosen Pemula fiscal year 2020, Grant No. Kept. 121/UN23.18/PT.01.05/2020 with the proposal entitled "Pendidikan Antikorupsi Dalam Buku Sekolah Pelajaran Bahasa Inggris Untuk SMA Kelas XII"

\section{REFERENCES}

Dalilan, D. (2012). Strategies in Expressing Thanking in English Realized by Indonesia Learners. Indonesia Journal of English Language Teaching, 8 (1), 51-71. https://doi.org/10.25170/ijelt.v8i1.90

Dharma, Y. P., \& Aristo, T. J. V. (2018). An Analysis of English Textbook Relevance to the 2013 English Curriculum. Journal of English Educational Study, 1 (1), 24-33. https://doi.org/10.31932/jees.v1i1.277

Ifrani. I. (2017). Tindak Pidana Korupsi Sebagai Kejahatan Luar Biasa. Al'Adi, X (3), 319-336. http://dx.doi.org/10.31602/al-adl.v9i3.1047

Herlinda, R. (2014). The Use of Textbook in Teaching and Learning Process (A Case Study of Two EYL Teachers). Proceedings of The 61 TEFLIN International Conference. p. 359-352. Retrieved Oktober 20, 2019 from https://eprints.uns.ac.id/26887/1/Proceding_TEFLIN_2014_Book_1.379-382.pdf

Kementrian Pendidikan dan Kebudayaan. (2018, 12 December). Pendidikan Antikorupsi di Sekolah Bukan Menambah Mata Pelajaran Baru. Retrieved November, 19 2019, from https://www.kemdikbud.go.id/main/blog/2018/12/pendidikan-antikorupsi-di-sekolah-bukan-menambahmata-pelajaran-baru

Knight, B. A. (2017). Teacher's Use of Textbooks in the Digital Age. Cogent Education. 2 (1), 1-10. https://doi.org/10.1080/2331186X.2015.1015812 
4243 Anti-Corruption Values Potrayal in English Textbooks for Senior High School Grade XII: Critical Discourse Analysis Perspective - Prayogo Hadi Sulistio, Erna Wardani

DOI: https://doi.org/10.31004/edukatif.v3i6.1420

Komisi Pemberantasan Korupsi. (2017). Pendidikan Anti Korupsi: Modul Penguatan Nilai-nilai pada Pendidikan Dasar dan Menengah. Retrieved August 20, 2019 from https://aclc.kpk.go.id/wp-content/uploads/2018/07/Modul-PAK_SMP.pdf

Kristiono, N. (2018). Penanaman Nilai Anti Korupsi Bagi Mahasiswa FIS UNNES Melalui Mata Kuliah Pendidikan Anti Korupsi. Jurnal Ilmu Pendidikan, 9 (1), 40-45. https://doi.org/10.24176/re.v9i1.2807

Mandarani, V., Purwati, O., \& Santoso, D. R. (2021). A CDA Perspective of Cultural Contents in the English Junior High School Textbooks. Indonesia Journal of English Language Teaching and Applied Linguistics, 5(2), 237-250. http://dx.doi.org/10.21093/ijeltal.v5i2.671

Nadhif, A. (2017). Representation of Religious and Moral Values in The English Textbook for Indonesian Junior High School: A CDA Investigation. Kodifikasia: Jurnal Penelitian Islam, 11 (1), 79-104. http://dx.doi.org/10.21154/kodifikasia.v11i1.1148

Purwanto, S., \& Soepriatmadji, L. (2013). Politeness Strategies in Model Conversations in English Textbooks for Elementary School Students. Parole: Journal of Linguistics and Education, 3(1), 75-84. http://dx.doi.org/10.14710/parole.v3i1 April.75-84

Rapanta, C., \& Christodoulou, A. (2019). Walton's Types of Argumentation Dialogues as Classroom Discourse Sequences. Learning, Culture and Social Interaction, 1-15. https://doi.org/10.1016/j.lcsi.2019.100352

Rohmatillah, R., \& Pratama, D. A. (2017). An Analysis of Textbook Entitled "Pathway to English" Published By Erlangga at the First Semester of the $11^{\text {th }}$ Grade of Senior High School. English Education: Jurnal Tadris Bahasa Inggris, 10 (2), 326-343. https://doi.org/10.24042/ee-jtbi.v10i2.1754

Schat, Sean. (2018). Exploring Care in Education. International Christian Community of Teacher Educators Journal, 13 (2), 1-10. Retrieved from https://digitalcommons.georgefox.edu/icctej/vol13/iss2/2

Setiawan, I., \& Fahriany, F. (2017). Moral Values in Narratives Texts of English Textbooks for Senior High School Students Published by Ministry of Education and Culture. Indonesia Journal of English Education. 4 (2), 130-143. https://doi.org/10.15408/ijee.v4i2.5977.

Sholikha, S. N., \& Fitrayati, D. (2021). Integrasi Keterampilan 4C dalam Buku Teks Ekonomi SMA/MA. Edukatif: Jurnal Ilmu Pendidikan, 3 (5), 2402-2418. https://doi.org/10.31004/edukatif.v3i5.823

Simbolon, L. A. (2016). Konsep dan Gagasan Pengenalan Pendidikan Antikorupsi bagi Anak dalam Rangka Mewujudkan Generasi yang Bebas Korupsi. Jurnal Lex Librum, 3 (1), 389-400. http://dx.doi.org/10.46839/1ljih.v3i1.59

Sulistio, P. H., \& Wardani, E. (2020). Nilai Anti Korupsi Pada Buku Teks Pelajaran Bahasa Inggris Kelas XII Sekolah Menengah Atas. Prosiding Seminar Nasional dan Call for Papers: Pengembangan Sumber Daya Perdesaan dan Kearifan Lokal Berkelanjutan X. 327-332. Retrieved December 10, 2020 from http://jurnal.lppm.unsoed.ac.id/ojs/index.php/Prosiding/article/view/1361/1168

Sulistiyo, U., Supiani, Kailani, A., \& Lestariyana, R. P. D. (2020). Infusing moral content into primary school English textbooks: A critical discourse analysis. Indonesian Journal of Applied Linguistics, 10(1), 251260. https://doi.org/10.17509/ijal.v10i1.25067

Tendi. (2019, January 29). Transparency International rilis indeks persepsi korupsi, di mana posisi Indonesia? Kontan. Retrieved November 18, 2019, from https://nasional.kontan.co.id/news/transparency-international-rilis-indeks-persepsi-korupsi-di-manaposisi-indonesia

Widodo, H. P. 2018. A critical micro-semiotic analysis of values depicted in the Indonesian Ministry of National Education-endorsed secondary school English textbook. In H. P. Widodo et al. (eds.), Situating moral and cultural values in ELT materials: The Southeast Asian context (pp. 131-152). Springer International Publishing AG.

Wulandari, G., \& Indihadi, D. 2021 Analisis Teks Deskripsi melalui Media Gambar Tunggal di Sekolah 
4244 Anti-Corruption Values Potrayal in English Textbooks for Senior High School Grade XII: Critical Discourse Analysis Perspective - Prayogo Hadi Sulistio, Erna Wardani

DOI: https://doi.org/10.31004/edukatif.v3i6.1420

Dasar. Edukatif: Jurnal Ilmu Pendidikan, 3 (5), 2345 - 2354. https://doi.org/10.31004/edukatif.v3i5.811

Wulandari, Y., Damayanti, I., \& Harahap, A. 2018. The Analysis of the Proportion of Language Skills in English Textbook Grade XI Published by KEMENDIKBUD 2014. Journal of English Education and Teaching, 2 (3), 40-49. https://doi.org/10.33369/jeet.2.3.40-49.

Zuber, A. (2018). Strategi Anti Korupsi Melalui Pendekatan Pendidikan Formal Dan Kpk (Komisi Pemberantasan Korupsi). Journal of Development and Social Change, 1 (2), 178-190.

https://doi.org/10.20961/jodasc.v1i2.23058 